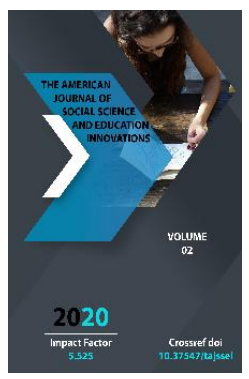

\title{
Theoretical-Practical And Epistemological Review Of Political Linguistics
}

\author{
Mokhira Eshanova Yuldashbaevna \\ Senior Teacher, Specialized Branch Of Tashkent State University Of Law, Uzbekistan
}

Journal Website:

http://usajournalshub.c

om/index,php/tajssei

Copyright: Original

content from this work

may be used under the

terms of the creative

commons attributes

4.0 licence.

\section{ABSTRACT}

Political text and discourse is a combination of perceiving the life in terms of conceptual-discourse methods, standards of scientific researches and activities. The primary form of analyzing a text identifies hidden factors of its political and ideological objectives as they reflect socio-political changes turning to setting the target for investigating, evaluating and selecting. This can help clearly define epistemic-linguistic problems and the frame of the tasks in developing national idea.

Currently, the prosperity of Uzbekistan has its reflection on the development of the Uzbek language and its application in people's lives. Language is the basis of political life, hence, political thinking remains unchanged unless national language develops. In this view, it's essential to investigate argumentative issues of the essence of political linguistics, the interrelation, the main idea that determines the notion of political discourse in terms of political-philosophical aspects. For this reason, the article mainly focuses on political language and its peculiar features.

Political language constitutes different spheres of a culture, interpretation of the lexis delivered during propaganda and political events within various strata of population, as well as timeliness to strengthen the link with population.

\section{KEYWORDS}

Political linguistics, political text and discourse, hidden factors, socio-political events, political communication 


\section{INTRODUCTION}

Political linguistics is a contemporary trend of practical linguistics which focuses on investigating the important features of political language, political communication and discourse. In addition, political linguistics studies the essential methods of rendering ideological expressions in a political text and they are analyzed on the basis of their scientific concept. Here, a political text appears as the initial existence and the key point of a socio-political event. It reflects all characteristics of political and ideological expression including its communicative, comprehensive and heritage based nature. The important form of analyzing a text is to identify hidden factors of political-ideological tasks and functions of it. The hidden content, spiritual heritage and political-ideological principles to be meant is characterized in details alongside with socio-economic changes turning to become the core object of carrying out research, evaluation and selection process.

However, it's worth stressing out that to influence on the object to some extend is the objective of any text. In this regard, the Russian scientist A. Altunyan expressed, "Information compiled in any political text possesses potential power. It depends on an author's description how to render the information on the emergence of the universe. This also helps to identify the author's outlook as well as his/her understanding of the world policy and the principles of his/her attitude towards it."

\footnotetext{
${ }^{1}$ A.G. Altunyan, Analysis of political texts. M.: University Book, Logos, 2006. - p.7
}

\section{Political text and discourse: the concept and the content}

The structure based functional analysis of political linguistics was initially elaborated by Plathon and Aristotle, later by those philosophers such as J. Bull and J. Mill. One can hardly perceive philosophicalepistemological essence of political linguistics without understanding its notional meaning. The issues related to bases of political linguistics, its structural nuances, its interaction with other linguistic trends as well as linguistics development process have been investigated in the research works of such scholars as $M$. Bakhtin, R. Barthes, L.Wittgenstein, H. Gadamer, D. Davidson, J. Dales, W. Quine, J. Lacan, Y. Lotman, P. Ricoeur, E. Sapir, M. Heidegger, G. Frager, and M. Foucault. ${ }^{2}$

\footnotetext{
${ }^{2}$ M.M. Bakhtin, Aesthetics in Written Works. M., 1979. R. Barthes, Selected works: Semiotics. Poetry. -M.,1989. L. Wittgenstein, Philosophical works. - M., 1994. H. Gadamer, Truth and Method. - M., 1988. D.Davidson, Truth and Meaning // News in foreign linguistics. - M.,1986. J.Dales, Logics of meaning. - M., 1995. W.Quine, Word and Object // News in foreign linguistics. - M., 1986. J. Lacan, The Function and Field of Speech and Language in Psychoanalysis. M., 1995. Y.M. Lotman, Lectures on structural poetics // Y.M. Lotman and Tartu-Moscow Semiotic School. - M., 1994. P.Ricoeur, The Conflict of Interpretations. - M., 1995. E. Sapir, Selected publications on language studies and culture studies. - M., 1993. M.Heidegger, Language. - SP., 1991. G.Frager, Thought // Logics. Philosophy. Language. - M., 1987. M.Foucault, What is an author? Discourse order // Will to knowledge. - M., 1997.
} 
The achievement of the independence of our republic made it possible to survey problems and some issues concerning political linguistics openly to analyse it in terms of philosophical view in theoreticalmethodological framework. In particular, it is providing an appropriate evaluation to identify the position of the Uzbek language in our heritage and history related values. In this regard, the research works of K. Honazarov, D.A. Mamashukurov, R.G. Safarova, Sh.N. Kuchimov, Sh.Kh. Shakhabitdinova and other scholars serve to be the scientific-theoretical fundamentals in this subject area. ${ }^{3}$ For instance, K. Honazarov interprets, "Language is a tool. With its help we understand and learn the world. We also relieve the truth from the false".

As for epistemiological research, it's essential to apply integrity and history based principles to deal with political texts. The integrity stands for the structure of a political text, and studying separate component units linking to the text as a whole. That is because I.F.

3 K. Honazarov, Globalisation and language philosophy. - T., Institute of Philosophy and Law, 2009. -136p. D.A. Mamashukurov, Sociopolitical and spiritual bases of developing the Uzbek language as a state one, Dissertation for Candidacy of Philosophical Sciences. - T., 1999. -136 p. R.G. Safarova, Mother tongue teaching theory and practice in Uzbekistan schools in the condition of national retrieval process, Dissertation for obtaining Doctor of Pedagogical Sciences. - T., 1998. - 255 p. Sh.N. Kuchmanov, Scentific-practical problems of rendering legal norms in the Uzbek language, Dissertation for obtaining Doctor of Philological Sciences. - T., 2004. - 290p. Sh.Kh. Shakhabitdinova, Common and specific dialectics and its reflection in Morphology of the Uzbek language. Dissertation for obtaining Doctor of Philological Sciences. -Andijan, 2001. $-233 \mathrm{p}$.
Oukhvanova-Shmygova explains, "Studying a political text to link with the context and cognitive meaning requires comparative investigation of one text with that of another author."4 These seem to be simple requirements, though it appears to be complicated procedure. It means that the integrated approach evolves to identify and scrutinize the hidden features of a text. Alongside, it makes possible to understand a text and its relationship with existing sociopolitical conditions, in general, with political culture of a society.

A political text fulfills a number of tasks. In this term, it encompasses the state of a certain political leader and his mentality, which can be useful to create his politicopsychological portrait. A. Chudinov attempts to describe political text according to their content and objective. He thinks that the content-based indicator of a political text is reflecting the activities focused on developing socio-economic structure, in all senses, of leaders of parties and public organizations, state governing bodies as well as state and public sector leaders. Objective based indicator of political texts is considered to have sensitive influence on a state's citizens' feelings in the propaganda of specific ideas to have them get involved in that political

4 I.F. Oukhvanova-Shmygova, Cause based analysis of a political text / Methodology of researching a political discourse: Actual problems of content based analysis of sociopolitical texts: collection of research worsks / Belorussian State University, under the review of I.F. Oukhvanova-Shmygova, 1st issue. Minsk, 1998. - p.p. 45-52. 
process through having impact on that political situation. ${ }^{5}$

The cognitive knowledge of socio-political knowledge is a way to study not only the relashionship between a text and national heritage, but current policy and its characteristics as well as the direct mean to express political changes.

According to N.G. Yuzefovich "Socio-political interpretation of a text raises an issue of both its reflection of political culture related events and socio-political existence". ${ }^{6}$ In addition to linguistic and literal characteristics of a text, its gnoseological characteristics plays a primary role in analyzing a text.

Political text is a part of cognitive activity that gives the opportunity to srutinize different levels and forms of the reflection of the universe. Whereas, political discourse includes all extra linguistic description of political communication in terms of pragmatic, sociocultural, and psychological aspects. According to E.E.Chizevskaya, political discourse is a text to illustrate different ways of expressing one's opinion in logical consistency. ${ }^{7}$ That includes

\footnotetext{
${ }^{5}$ A.P. Chudinov, Metaphorical Mosaics in the Modern Political Communication -

Yekaterinburg, 2003. - p. 248.

${ }^{6}$ N.G. Yuzefovich, Political discourse and crosscultural communication / N.G. Yuzefovich // Interpretation. Understanding. Translation., collection of scientific articles / St. Petersburg State University of Economics and Finance; V.E.Cheryavskaya, editor in chief. - Saint Petersburg, 2005. - p.p. 231-240.

${ }^{7}$ Чижевская Е.Е. Дискурс политика / Е.Е.

Чижевская // Методология исследования политического дискурса: Актуальные проблемы содержательного анализа общественно-политических текстов: сб. науч. трудов / Белгосуниверситет; под общ. ред.
}

talks, lectures, interviewing, and formal negotiations within political discourse related political activities. Here, political rhetoric plays a specific role in the political discourse. It can be seen through demonstrating public speech related skills in the political discourse. On this stage a person develops his/her political intellectual culture. It also enhances the skills on how to link ideas, making up consistent idea and creating new relevant ideas. In this regard, by means of analyzing Shavkat Mirziyoev's, the president of Uzbekistan, speeches and addresses one can be evident that he is able to objectively and accurately evaluate current socio-political events as well as pass them on to the public. In particular, the President's addresses in the meetings hold in the Cabinet of Ministers, the Senate, the Legislative Chamber, and his speeches in the regional sessions show thorough preparation as he provides clear facts and figures, subsequently, putting forward clear cut tasks, and occasionally using some jokes to encourage high spirit of the public, prove that he can do it very skillfully.

In political discourse a political communication text equally plays an important role. To develop a political communication text, it is essential to command the important features and possibilities of a national language. It includes learning different ways of creating a political communication text, completing this text, and drafting a new text.

The basic objectives of developing the skills relevant to political communication text contain to master public speech skills, acquire political knowledge and skills as well as continuously improve them.

И.Ф. Ухвановой-Шмыговой. - Вып. 1. Минск, 1998. - С. 161-170. 


\section{Conceptual characteristics of political text}

Currently, the formation of youth's political view plays an important role, as the contemporary generation are tend to become potential politicians of tomorrow. The measures are being undertaken in order to make them comprehend the concepts of "state", "society". "governance" and alike terms alongside with the conception of existing policy and future prospects by providing quality education and involving them in the political processes taking place in Uzbekistan. The issues of developing youth's spirituality, their education and world outlook as well as their active participation in political life seem to be crucial today, otherwise they may become targets for those opponents who attempt to interfere with and have an adverse influence on the country's peace and development through provocations. In this term, political linguistics and discourse give the opportunity to prevent the youth from following violent cohorts and combating those intending evil towards the land. It should be stressed out that in order to determine its own way of progress each state is concerned about upbringing harmoniously developed generation who are able to see the colours of the happenings. A person is capable to achieve perfection only if he strives to reflect good will, justice and kindness for others. Hence, a complete person cares about his motherland, family, and parents. Abu Nasr Farobiy writes: "A wise person is the one who possesses high intelligence, deep thinking as well as other features. This person should be committed to use those features for the sake of goodness and avoid to do bad deeds to be considered a wise man with logical thinking". ${ }^{\circ}$

Political text plays a significant role in forming and developing the essentials of youth's political thinking and politival overview which helps bring them up the ones who have independent personal opinion and capable to resist against external spiritual and ideological attacks. It also can be used as tool for protecting the youth from the evil oriented intentions against our national political interests and our mode of life through organizing the activities focused on enlarging their political awareness. To do this, our youth must not be indifferent to political processes taking place in the society. In his work of "Donishnoma" (The Wise Stories) Abu Ali Ibn Sino defines theoretical and practical knowledge, here he divides practical knowledge into three, the first is governing the country and the second one is related with managing the household. He says that a person might skip those two types of knowledge, however he must be confident that he possesses the third one, self-control, by asking himself such questions as "Why was I born? What is the goal of my life? What have I given to my motherland and the people?". The latter has the power to make a person to be conscious and stand against being careless, indifferent and blind imitation, versus developing humane qualities.

The word "text" was originated from Latin "textus" which stands for "fabric", "thing woven", "joint", ect. Text is considerd to be the primary and core point of any social and political subject. It encompasses communicative, essense, and political

\footnotetext{
${ }^{8}$ Абу Наср Форобий. Фозил одамлар шахри.

-Т.: 1993. - Б. 134
} 
inheritance based characteristics. In general, text is one of the topical isses of the subjects like linguistics and literature studies. However, in the contemporary world, in most Western countries the political analysis of a text is being widely studied within the frame of linguistics and discourse. ${ }^{9}$ From this point of view, it is vital to carry out goal oriented assessment of the role of political text in the social and spiritual life of a society. Hence people get ethtetical satisfaction from addressing and dealing with political texts due to the fact that it gives the opportunity to reveal the truth, compare personal opinion, and re comprehend their notion hidden behind that political event. These were the reasons why political text had a significant influence on the spiritual world of the subject. Here, it eliminates the threat of "symmetry" destroying consciousness, spiritual inheritance and "matter" between the object and the subject. $^{10}$

A human, comprehending political text, carries a significant essence. Also, it's contemporaray requirement to create scientific methods of learning and reviewing political texts. From this point of view, the surface view of political text and its rich categories may not show the indicator of its being of practical importance and its productivity. It's obvious that using complex linguistic categories in political text is

\footnotetext{
${ }^{9}$ Терехова Евгения. Двусторонний перевод общественно-политических текстов (с элементами скорописи в английском языке). ФЛИНТА ИЗДАТЕЛЬСТВО, НАУКА/ИНТЕРПЕРИОДИКА МАИК, 2006.

${ }^{10}$ Павлова Н. Д., Ушакова Т. Н. Слово в действии. Интент-анализ политического дискурса / под ред. Т.Н. Ушаковой, Н.Д. ПавЛовой. АЛЕТЕЙА, 2000.
}

essential, however it's not sufficient to reach its complete essence and practicability. ${ }^{11}$

It can be insufficient ot develop criteria to identify and to assess the quality of the outcomes of political thinking through the diversity of views based on the idea of the categories of political linguistics. As a person with deep political knowledge and good memory is able to express anything that he needs to decode. However, a political leader needs to identify for himself the level and the power of his speech, what part of the content is original and/or imported. If the latter is committed, then, he must be definite about what way it should be selected, recomposed and delivered. It's no reasonable to consider a political text as an influential source if it has complex categories when compared with a more "modest like" one. That's because, if we scrutinize the latter it may carry new and primary sides of the political universe free of those randomly used categorized sources. For instance, "some political event has happened", "some political methods have been used", "some political event has been identified", etc. may sound very simple and common. It's obvious, it is not true that a political leader proves to invent and reveal new facts if he frequently uses "superior" political terms in his political text. Consequently, people read these political texts and comprehend, and acquire the language of political culture. This skill helps enhance the creation of new texts with new political essence.

\footnotetext{
11 Алтунян А. Г. От Булгарина до Жириновского. Идейно стилистический анализ политических текстов. -М.: Российск. гос. гуманит. ун-т, 1999. - С.263.
} 
Another significant feature is that political text contains norms snd standards existing in society, and other components related with behavioural stereotypes, political symbols and national and spiritual heritage. Culture also plays an important role in interpersonal relations in the process of socio-historical development. Nation specific political stereotypes and its heritage tend to have its power and place in people's mindset of every nation. In this term, national policy and its culture, state language and its emblems have their reflection in national political essence and philosophy. Consequently, people belonging to one or another nation can identify their national identity in their national culture. And this can be noticed in their behaviour towards political culture, political viewpoint and their mode of lives alongside with their attitude to socio-political procedures. "The political culture is considered the views about the set of rules and the heritage on specific laws and the way of their implementation as well as its policy of various nations and socio-political units. It also reflects political traditions, functioning political standards, ideas and concepts developed for a long time and valued by various generations". ${ }^{12}$

In order to objectively assess the results of political culture, it will be necessary to deviate from the scope of a particular political text or its passage. Because, in order to give a worthy assessment of someone else's opinion and the political output that he created, it will be necessary to compare them to Universal views, to existing political knowledge in society. That is, the identified political

12 Эргашев И. Сиёсат фалсафаси. - Тошкент.: “Академия”. 2004. - Б. 27. categorical structure is sufficiently thoughtful, while the assessment given is considered complete and objective. It's true that sometimes the word itself through the text, the consciousness of the person is absorbed into the traditions and culture in which it does not belong. Knowledge of the universe and other cultures gives the impression of communicating with some stranger. Everything: other worlds, histories, cultures, societies, minds can be alienated. In order to know a stranger, it is necessary to translate, from "alien" language to "own". The mechanism of turning from one language to another is the peculiarity of the life activity of people. Thanks to this soundness, people will understand each other, thus it will be possible to achieve the understanding of members of one society in another society.

Any political information, information expressed in the political text, can not be all political knowledge. After all, one of the peculiarities of political knowledge is the introduction of innovation into the circle of thought of the politician. That is, through the same political text, it enters a new world and acquires a new meaning. On the basis of the purpose set out in the political text, the reader draws new goals, conclusions within the framework of his thought. In understanding political reality, the structural structure of the political text plays an important role. Because the choice of the most yellow of several words with similar meaning in the political text has a positive effect on the understanding of the meaning. Also, skillfully selected some political words can not be replaced by another meaningful word. In addition, the clear, concise and concise transfer of words in the political text serves to make the new knowledge take an easy place 
from the circle of consciousness. The political text does not have any value on its own, it must be a meaningful text and an aspiring researcher to gain new knowledge. Therefore, behind any political text always lies the author's own interests, worldview, tastes, strengths and weaknesses, writing and reading skills, memory, general knowledge, features of development.

The socio-political interpretation of the political text reveals not only its existence as a phenomenon of political culture, but also the problem of reflection of political presence in it. ${ }^{13}$ Here, the ontological description of the text comes to the fore. That is, the political text gives the opportunity to simultaneously analyze the different levels and forms of reflection of political existence. This, firstly, characterizes the description of the content of some political events and the attitude of the subject to them, and secondly, through political poetics, context and secondary it reflects the political ideas of the author, the political life of that period. Thirdly, the interpretations carried out by foreign politicians in the political text are also expressed. In this regard, it should be noted that logical consistency is of paramount importance in determining the hidden content of political texts. Hence, intuition, relying on various hypotheses and assumptions. "Another feature in determining the hidden content of the political text is that a researcher of other cultures in relation to adult people in the bosom of this culture, may be one of the hidden meanings unknown in

\footnotetext{
${ }^{13}$ Алимов В.В., Артемьева Ю.В.
}

Общественно-политический перевод. Серия "Практический курс перевода" - M. : URSS, 2007. - C. 272. this text" writes A.Krivonosov. ${ }^{14}$ Such a feature of political texts is objective, it is not created by politicians, but it occurs either consciously or unconsciously in this or that culture. Thus, the political text has objective characteristics that ensure its practical existence and succession.

If the political text belongs to another culture, it will be significantly more difficult to understand and interpret it. Because the approaches of political theorists may not be appropriate. As a result, there will be controversy. They can also be reflected in the manner of national political goals and interests. Consequently, political texts watered by the spirit of humanism are distinguished by an impartial reflection of political life. And this comes from the understanding that it is a materialized expression of spiritual culture. In this regard, firstly, there are sources of different understanding and interpretation of any political text. Secondly, the multiplicity or openness of political ideas in the political text can not be manifested at once and immediately. That is, in such a text the meanings are hidden and manifest themselves when favorable conditions for development appear in the coming periods. Thirdly, in the process of historical development, its political meaning changes. Ideas that are considered politically correct for a particular period may not be accepted as correct afterwards. Fourthly, understanding the political text is a dialectical process, and not a finished result.

\footnotetext{
${ }^{14}$ Кривоносов А. Д. PR-текст в системе публичных коммуникаций / А. Д. Кривоносов. - СПб. : Изд-во С.-Петербург. унта, 2002. - С. 24.
} 
Because, here, there is a struggle of different political goals and interests.

In general, the political text and its politicalphilosophical nature are the details of events, processes expressed through linguistic methods and means in the form of a certain composition, structure. A thorough understanding of its essence plays an important role in the life of the state and society, in particular, in the upbringing of a harmonious generation. After all, the political text and the approach to it is a guarantee that young people, the people and the nation will get rid of various errors, biased and erroneous interpretations, analyzes, and thus ensure the need for a sustainable development and approach to our national interests, based on our national identity.

\section{Socio-cultural characteristics of the political language}

Politics and its institutions cannot accomplish their goals without language opportunities in the society. At the same time, the language itself is also influenced by politics in this or that way. It is known that language becomes an object of individual policy and planning by the state. In the literature, such phrases as "special political language", "functional style of politics", "special lexical composition of politics", "special political lexics" are identified. In our view, the concepts of "political language" and "political term", first of all, are synonymous combinations, and secondly, have a somewhat general meaning in relation to the combinations of "special political language" and "functional style of politics". Consequently, they will cover as fully as possible the issue we are studying.
Now, let's try to answer the question "What is the specifics of the language of politics?". The linguistic scholar V.Schmidt explains it as follows: "A common sign of political lexicon is its ideology". We do not agree with this opinion, because first of all there are political, legal, religious and other types of ideology. Of course, it is clear that V.Schmidt refers to exactly political ideology, and not to a different ideology. Secondly, does political consciousness go to political ideology? It is debatable issue either. Thirdly, ideology is such a spiritual product, in which reality is reflected through the prism of private interests. Such expression of social reality in consciousness is political consciousness. But this is not an exhaustive conclusion, because in it social psychology is set into. ${ }^{15}$ But this is not an exhaustive conclusion, because it is based on social psychology. Now we will return to the language of politics again. To do this, we need to determine the general specificity. Language is a system that constantly changes, performs tasks such as expressing the opinion of society, expressing, studying, rendering information, communication. It is also a specific sociocultural tool for the storage, aggregation and delivery of information, human activity, and management of behaviour.

As a rule, in the functioning and development of the language, researchers distinguish its "two interrelated sides: the structure of the language and the language, which makes it possible to consciously intervene in the

\footnotetext{
${ }^{15}$ Шмидт В. Соотношение языка и политики как предмет исследования социальной эффективности языка с позиций марксизмаленинизма // Актуальные проблемы языкознания ГДР. Язык - идеология общество. М., 1979.
} 
processes of development of social functions". In our opinion, such independence is not an absolute independent phenomenon, although it occurs in the conditions of various historical epochs and political order. Because language is represented as a social and sociohistorical phenomenon. By the way, the language obtained in terms of its structure or construction will be more independent than the language chosen according to its social functions. However, since this is perceived as a feature of all languages, it is difficult to distinguish the specificity of the language of politics, its reforms in the life of society, the policy pursued by the head of the country and its implementation by the political elite from the interpretation of the language and its devices, processes. From now on, language should be looked at in the context of society and culture. In this place it is possible to distinguish a number of languages. Such a changing situation arises from the fact that society and culture are complex structures. And also different spheres of culture (science, religion, art, politics, law, etc.) are available. Each of such spheres forms its own language. In addition to these specialized areas in society, there is also an unfixed sphere of everyday life. In it, the so-called "natural language " is a language, that is, which has been formed for many centuries and is manifested in the daily life activities of people and as a means of interaction. In a developed culture, this language will exist in two main forms: 1) ordinary folk language; 2 ) in the form of literary language. Since natural language is not specialized, it is considered non-functional language.

Languages that serve relatively independent spheres of society are created within these spheres and are therefore called specialized languages. It's obvious, such a language can not exist without a natural language (first of all, without a literary language). But the natural language is also subordinated to the language sphere in which it is used. Specialized language is used within the framework of a special sphere and activity (by profession, by type of training, etc.), so it is a functional language. In this regard, it should be noted that any language - both functional language and non-functional language-has its own functional function. Consequently, in this case, it is not about the functional system of the language, but about the functionality of the whole language. The peculiarity of the language of policy or political language is that it is considered a mean of political implementation, achievement of political goals. In this aspect, it differs from legal, scientific, philosophical, medicine and any other functional language. But the language of policy is closely related to all the rest of the language, the composition of the general language lexicon. At present, the language of policy is not as clearly distinguished as the language of medicine, technology or jurisprudence.

Against this background, there is a constant interchange between the policy language and the general language lexical content: political terms, words and phrases become a wealth of common language lexical content, on the contrary, many words and phrases in the general language lexical content go into the policy language content.

In this way, political terms at this or that level lose their terminological character, while words in the general language dictionary are given special (political) meanings. According to $V$. Schmidt the result of the above anti- 
dependence trends is the co-existence of political language and common language homonyms ${ }^{16}$.

The peculiarities of the political language can again be explained by the following, firstly, politics begins to interact with different spheres and levels of society, which often occurs more directly than other spheres. Because politics is intended for the whole society (of course, it considers domestic politics), political processes cover all groups and strata of the population. Secondly, this form of language is used in political struggle, discussions, persuasion of one's own way and in other cases. Thirdly, another of the most important features of the policy language is that it is able to gain the trust of who it is aimed at.

The language of politics is a diverse and holistic thing. It has a certain structure. This structure can be considered as 1) the core and a number of concentrated circles around it; 2) in the form of a series of stages subordinated to each other. In our view, these two models complement each other, and when taken separately, they do not reflect the whole structure of the policy language. In the first model, special political terms serve as the basis. It carries an important task in the field of politics. M.M. Bakhtin writes about the originality of the term: "In the term, although it does not come from a foreign language, there is little stabilization of meanings, weakening of the power of metaphors, much meaningfulness is lost. The fact that the term has one meaning distinguishes it from other concepts." In our opinion, political terms do

\footnotetext{
${ }^{16}$ Schmidt, Der Diskurs des Radikalen

Konstrukti-vismus, Suhrkamp, Frankfurt am Main (1996), 7. Aufl.
}

not always have a strict meaning. In different political systems, exactly the same meaningful words can express completely opposite views. Such a situation is also difficult to meet in such areas as law, medicine and technology. It is known that policy is divided into foreign and domestic policy, and domestic policy is divided into a number of sectors (economic policy, cultural policy, policy in the field of education, etc.). Therefore, the basis of the policy language lies in its terminology: a) terms that are common to all types of policies (that is, both domestic and foreign policy); b) terms that are relevant to foreign and domestic policy are distinguished. But domestic policy, in turn, is divided into sectors. Consequently, even here, terms that are common to the whole domestic policy and are inherent only in one of its branches are distinguished. The political language is assimilated from the language of different spheres of culture and different strata of the population, with the aim of propaganda, interpretation of the essence of political events, recognition to the masses, that is, strengthening public relations where the lexicon reflects its expression.

\section{CONCLUSION}

The upper stage of the political language is considered the official language. This is the language of various declarations, statements, memoranda, notes in foreign political activity, and in domestic political activity-political programs, decisions, decrees, etc. This language consists of strictly selected, tested terms. They are emotionally neutral and are mainly intended for the intellectual level of the audience. And on the bottom of it there is a language that expresses communication, relationships. Its task is to reach an agreement 
between the parties involved in the dialogue (it can be representatives of other states, parties or organizations) or to ensure that the interests at the language level are common. The language of diplomatic communication belongs to this level. It's a little flexible. Below it there is the language of political education. Its task is to achieve normative structures and formulate political approaches of citizens. Such a language is characterized by emotionality, expressiveness, flexibility and relying on evidence-proof. The language of political education is widely used in the field of education, mass communication. The lowest level of political language structure is the language of political propaganda and is used in the process of propaganda to change the structure of political speeches, party values and opinions or, conversely, to strengthen them. It is in many respects similar to the language of political education, but not as flexible and full of evidence as it is. In this language, special political terms are almost not used, but they are used in the case of avoidance and exaggeration in the evaluation, etc. This language is widely used in election campaigns, especially when RR technologies are used.

Language at the level of political propaganda is quite abstract. The reason is that it is intended for as wide an audience as possible. In it, the slogans occupy a special place. They are extremely functional words, are an integral part of popular speech in the field of thought formation and transformation.

The word itself does not turn into a slogan. For example, such words as "democracy", "progress", "unity" are not used in the language of science in the sense of slogan, these are categorical concepts of a certain sphere, more precisely a democratic society. And this is regarded as the interpretation of socio-political processes, having a certain informative, ideological significance.

In conclusion, the political language is manifested as an expression of the processes associated with the life of a society with a complex structure, the internal and foreign policy of the state. It is the combination of social, political, cultural life and the possibility of realization of political goals and tasks on the basis of certain interpretations, national interests and, it is important in the life of the state and society, in the political decisionmaking related to human interests.

\section{REFERENCES}

1. A.G. Altunyan, Analysis of political texts. M.: University Book, Logos, 2006. - p.7

2. M.M. Bakhtin, Aesthetics in Written Works. - M., 1979. R. Barthes, Selected works: Semiotics. Poetry. -M.,1989. L. Wittgenstein, Philosophical works. - M., 1994.

3. H. Gadamer, Truth and Method. - M., 1988. D.Davidson, Truth and Meaning // News in foreign linguistics. - M.,1986. J.Dales, Logics of meaning. - M., 1995.

4. W.Quine, Word and Object // News in foreign linguistics. - M., 1986.

5. J. Lacan, The Function and Field of Speech and Language in Psychoanalysis. - M., 1995.

6. Y.M. Lotman, Lectures on structural poetics // Y.M. Lotman and Tartu-Moscow Semiotic School. - M., 1994. P.Ricoeur, The Conflict of Interpretations. - M., 1995. 
7. E. Sapir, Selected publications on language studies and culture studies. - M., 1993.

8. M.Heidegger, Language. - SP., 1991. G.Frager, Thought // Logics. Philosophy. Language. - M., 1987.

9. M.Foucault, What is an author? Discourse order // Will to knowledge. - M., 1997.

10. K. Honazarov, Globalisation and language philosophy. - T., Institute of Philosophy and Law, 2009. -136p.

11. D.A. Mamashukurov, Socio-political and spiritual bases of developing the Uzbek language as a state one, Dissertation for Candidacy of Philosophical Sciences. - T., 1999. $-136 \mathrm{p}$.

12. R.G. Safarova, Mother tongue teaching theory and practice in Uzbekistan schools in the condition of national retrieval process, Dissertation for obtaining Doctor of Pedagogical Sciences. - T., 1998. - 255 p.

13. Sh.N. Kuchmanov, Scentific-practical problems of rendering legal norms in the Uzbek language, Dissertation for obtaining Doctor of Philological Sciences. - T., 2004. $-290 p$.

14. Sh.Kh. Shakhabitdinova, Common and specific dialectics and its reflection in Morphology of the Uzbek language. Dissertation for obtaining Doctor of Philological Sciences. -Andijan, 2001. - 233 p.

15. I.F. Oukhvanova-Shmygova, Cause based analysis of a political text / Methodology of researching a political discourse: Actual problems of content based analysis of socio-political texts: collection of research worsks / Belorussian State University, under the review of I.F. OukhvanovaShmygova, 1st issue. - Minsk, 1998. - p.p. 45-52.
16. A.P.Chudinov, Metaphorical Mosaics in the Modern Political Communication Yekaterinburg, 2003. - p. 248.

17. N.G. Yuzefovich, Political discourse and cross-cultural communication / N.G. Yuzefovich // Interpretation. Understanding. Translation., collection of scientific articles / St. Petersburg State University of Economics and Finance; V.E.Cheryavskaya, editor in chief. - Saint Petersburg, 2005. - p.p. 231-240.

18. Чижевская Е.Е. Дискурс политика / Е.Е. Чижевская // Методология исследования политического дискурса: Актуальные проблемы содержательного анализа общественно-политических текстов: сб. науч. трудов / Белгосуниверситет; под общ. ред. И.Ф. Ухвановой-Шмыговой. Вып. 1. - Минск, 1998. - С. 161-170.

19. Абу Наср Форобий. Фозил одамлар шахри. -Т.: 1993. - Б. 134

20. Терехова Евгения. Двусторонний перевод общественно-политических текстов (с элементами скорописи в английском языке). ФЛИНТА ИЗДАТЕЛЬСТВО, НАУКА/ИНТЕРПЕРИОДИКА МАИК, 2006.

21. Павлова Н. Д., Ушакова Т. Н. Слово в действии. Интент-анализ политического дискурса / под ред. Т.Н. Ушаковой, Н.Д. Павловой. АЛЕТЕЙА, 2000.

22. Алтунян А. Г. От Булгарина до Жириновского. Идейно стилистический анализ политических текстов. -М.: Российск. гос. гуманит. ун-т, 1999. - С.263.

23. Эргашев И. Сиёсат фалсафаси. Тошкент.: “Академия”. 2004. - Б. 27.

24. Алимов В.В., Артемьева Ю.В. Общественно-политический перевод. Серия "Практический курс перевода" M. : URSS, 2007. - С. 272. 
25. Кривоносов А. А. PR-текст в системе публичных коммуникаций / А. А. Кривоносов. - СПб. : Изд-во С.-Петербург. ун-та, 2002. - С. 24.

26. Шмидт В. Соотношение языка и политики как предмет исследования социальной эффективности языка с позиций марксизма-ленинизма // Актуальные проблемы языкознания ГДР. Язык идеология - общество. М., 1979.

27. Schmidt, Der Diskurs des Radikalen Konstrukti-vismus, Suhrkamp, Frankfurt am Main (1996), 7. Aufl. 